\title{
Leaf gas exchange and growth of Capsicum annuum var. glabriusculum under conditions of flooding and water deficit
}

\author{
E. MARTÍNEZ-ACOSTA*, L.C. LAGUNES-ESPINOZA*,+, M. CASTELÁN-ESTRADA*, \\ F. LARA-VIVEROS ${ }^{* *}$, and C. TREJO ${ }^{* * *}$ \\ Colegio de Postgraduados, Tabasco Campus, Plant Physiology Laboratory, Periférico Carlos A. Molina s/n, \\ CP 86500, H. Cárdenas, Tabasco, Mexico* \\ Polytechnic University of Francisco I. Madero, Francisco I. Madero, 42660 Tepatepec, Hidalgo, Mexico ** \\ Colegio de Postgraduados, Montecillo Campus, Botany Department, km 36.5 carretera Mexico-Texcoco, \\ CP 56230 Montecillo, Texcoco, Mexico State, Mexico****
}

\begin{abstract}
Growth and gas-exchange traits of Capsicum annuum var. glabriusculum under flooding and water deficit (WD) stress were measured in a greenhouse experiment. Flooding was applied to a group of plants for 0 (control), 5, and 10 d, and WD to another set at 100 (control field capacity), 70, 50, and 25\% of the water applied to control. Flooding negatively affected stomatal conductance, photosynthetic and transpiration rate from $20 \mathrm{~d}$ after transplanting (DAT), with a significant decrease in biomass at 120 DAT. WD at 70, 50, and 25\% severely affected the plant aerial and root biomass and the gasexchange traits from 80 DAT, inhibiting both flowering and fructification. This study showed the sensitivity of amashito chili plants to water stress which could have implications for the survival of local populations in natural conditions. Results should be considered for the development of small-scale cultivation.
\end{abstract}

Additional key words: foliar area; photosynthetic pigments; physiological traits.

\section{Introduction}

Changing global precipitation patterns causes increasingly frequent flooding or droughts, which vary in duration and intensity and affect agricultural production and biodiversity (Calanca 2017). Water stress produced by these climatic variations induces responses in plant species at both morphological and physiological levels (Akhtar and Nazir 2013, Osakabe et al. 2014), reducing growth and yield (Blum 2011, Gray and Brady 2016). In addition to the environmental and edaphic conditions experienced by the plant during development, the damage caused by these effects also depends on the phenological stage at the time of imposition of the stress, the species and variety in question and the intensity and duration of the stress itself (Anjum et al. 2011, Cramer et al. 2011, Calanca 2017).

Capsicum annuum, one of the five domesticated species of Capsicum genus, is economically important for its spicy and nutritional fruits, widely cultivated in the world with a great variation in forms, colors, and size (AguilarMeléndez et al. 2009, Antonio et al. 2018). This species is considered sensitive both to the excess and deficit of water, conditions that reduce plant height, foliar area, number of branches, photosynthetic pigment content, gas exchange, and the number and size of fruits per plant $(\mathrm{Ou}$ et al. 2011, Quintal et al. 2012, Gunawardena and De Silva 2014). Under conditions of flooding, different species of Capsicum reduce their photosynthetic pigments content, stomatal conductance $\left(g_{\mathrm{s}}\right)$, and transpiration rate $(E)$, while increasing their water-use efficiency (WUE) in order to reduce the stress; differences are observed between species in terms of their particular photosynthetic rates and response to the stress (Ou et al. 2011, 2017). On the other hand, plants subjected to water deficit reduce their foliar area, which decreases the area available for interception of light, while this stress also induces stomatal closure and decline in mesophyll conductance, affecting photosynthetic rates and biomass accumulation (Anjum et al. 2011, Galle et al. 2009, Liang et al. 2020). Campos et al. (2014) indicate that moderate to severe water deficit in chili reduces the assimilation of carbon due to the effect on stomatal conductance, but mainly to the damage produced in the electron transport chain from the pool of plastoquinones to the final acceptors of the PSI. Water stress also negatively affects root biomass accumulation (Kulkarni and Phalke 2009).

Received 19 November 2019, accepted 27 March 2020.

${ }^{+}$Corresponding author; e-mail: lagunesc@.colpos.mx

Abbreviations: ABA - abscisic acid; DAT - days after transplanting; DM - dry mass; $E$ - transpiration; FC - field capacity; $g_{\mathrm{s}}-$ stomatal conductance; $P_{\mathrm{N}}$ - photosynthetic rate; RGR - relative growth rate; RWC - relative water content; TM - turgid mass; WD - water deficit; WUE - water-use efficiency.

Acknowledgments: We thank to the National Council for Science and Technology (CONACYT) for the support provided to the first author to conduct his postgraduate studies and to the Project CP-CT-468 for the funding awarded. We also thank to the anonymous reviewers who with their sugestions and comments allowed to improve this manuscript. 
Wild Mexican populations of $C$. annuum are distributed throughout the country and the area from Sinaloa (northwest) to Tabasco (southeast) has been described as the center of domestication of $C$. annuum var. annuum (Aguilar-Meléndez et al. 2009). Within this area, C. annuum var. glabriusculum (Dunal) Heiser and Pickersgill is still found in its wild and semidomesticated forms as a highly branched herbaceous shrub, showing a high phenotypic plasticity (Hayano-Kanashiro et al. 2016). This species is an important genetic resource in breeding programs since it is considered the wild progenitor of $C$. annuum (Pickersgill 1971); its distribution range covers Central America, Colombia, and South of United States (AlcaláRico et al. 2019). The fruits of this species are consumed in many regional dishes, which generates a high demand for this fresh product (Salinas et al. 2010, Cano-Vázquez et al. 2015, Hayano-Kanashiro et al. 2016). In the state of Tabasco in southeastern Mexico, this species is known as the amashito chili and its fruits are collected from spontaneous populations that grow in domestic vegetable gardens, grazing pastures or beneath plantations, since cultivation of the species has not been developed at a commercial scale. This species grows throughout the year under tropical humid conditions, where periods of flooding alternate with seasons of drought produced by the variations in precipitation patterns that have occurred in recent years and that are predicted to intensify by the year 2050 (Arreguín-Cortés et al. 2014). These conditions, as well as seed dormancy, land use change, and the intensive application of agrochemicals, are among the main factors that affect the local populations of chili (Alonso et al. 2010, Castañón-Nájera et al. 2010, Prado-Urbina et al. 2015). Because of the interest in developing small-scale cultivation of this chili, pregermination treatments have been selected to break seed dormancy (Prado-Urbina et al. 2015), and studies have been started to focus on the chili's response to environmental conditions during its growth. Much information is available in the literature regarding the effects of water stress on the growth of economically important plant species, including the five currently cultivated species of the genus Capsicum: C. annuum, C. baccatum, C. chinense, C. frutescens, and C. pubescens. However, less attention has been given to the determination of the response of locally important plant species to different stress conditions experienced during their development, as is the case of $C$. annuum var. glabriusculum, despite the fact that such information could reveal the sensitivity degree of this species to such stresses to propose principles of diversity management and for its small-scale cultivation. Studies of the photosynthetic response, enzymatic activity, and morphological characteristics in other wild species of the genus Capsicum have shown that some of these species exhibit tolerance to water stress (Ou et al. 2011). For this reason, the present study evaluates the response of the amashito chili (C. annuum var. glabriusculum) to the continual effect of flooding and to water deficit during its growth, through measurement of its photosynthetic characteristics and accumulation of aerial and root biomass.

\section{Materials and methods}

Plant material: Fruits of the amashito chili were collected in May 2015 from wild plants growing spontaneously in a cocoa plantation in the ejido Rafael Martínez de Escobar of the municipality of Huimanguillo, Tabasco, Mexico $\left(17^{\circ} 43^{\prime} 26^{\prime \prime} \mathrm{N}\right.$; 9322 $\left.92^{\prime \prime} \mathrm{W}\right)$. The seeds were extracted from the fruits, washed with distilled water and left to dry on absorbent paper at ambient temperature in the shade $\left(30^{\circ} \mathrm{C}\right)$. Prior to establishment of the greenhouse experiment, viability tests were conducted using $1 \%$ tetrazolium chloride (Porter et al. 1947).

Experimental design: Two independent experiments were established using a completely random design, with factorial arrangement for each treatment (flooding or water deficit). For sowing, one lot of 200 seeds was treated with a solution of $500 \mathrm{ppm}$ of gibberellic acid $\left(\mathrm{AG}_{3}\right)$ for $24 \mathrm{~h}$, and then sowed in germination trays, using peat moss as a substrate and irrigating daily. The seedlings were transplanted $15 \mathrm{~d}$ after emergence into $30 \times 30 \mathrm{~cm}$ nursery bags, containing a substrate composed of soil from the collection site, compost (cattle dung and cocoa husk and filter cake of sugarcane) and vermiculite (proportion $10: 2: 1, \mathrm{v} / \mathrm{v})$. The substrate had $\mathrm{pH} 6$, with $0.32 \% \mathrm{~N}, 5.80 \%$ organic matter, $191.4 \mathrm{mg}(\mathrm{P}-\mathrm{Olsen}) \mathrm{kg}^{-1}$, and $2.34 \mathrm{mg}(\mathrm{K})$ $\mathrm{kg}^{-1}$. To establish appropriate moisture levels in the waterdeficit treatments, the water retention curve of the substrate was determined beforehand. Moisture of substrate at field capacity was $35.8 \%$ and at permanent wilting point $23.1 \%$.

The flooding treatments were applied at 20, 40, 80, and 120 DAT. Each treatment had five replicates per DAT interval, considering each plant as a replicate. At each of the 4 DAT intervals, the durations of the flooding treatments were 5 and $10 \mathrm{~d}$. All parameters were measured at the end of each flooding treatment. A control without flooding was considered in each flooding treatments and DAT. The experimental flooding was achieved by maintaining a sheet of water at $2.5 \mathrm{~cm}$ above the surface of the substrate. Daily, the loss of water from each nursery bag was compensated by the addition of water to maintain sheet level.

The water deficit treatments were applied at 40, 80, and 120 DAT. At each DAT interval, the amount of water applied to plants under water stress treatment throughout the study period was 100 (control FC), 70, 50, and $25 \%$ of the water volume that was added to FC. The moisture of substrate in each treatment was checked with a moisture meter (Kelway Soil Tester, Japan) and it was daily adjusted by adding water if necessary. At each DAT interval, each treatment included five replicates, considering a plant as a replicate.

Gas exchange: The rates of photosynthesis $\left(P_{\mathrm{N}}\right)$ and transpiration $(E)$ and the stomatal conductance $\left(g_{\mathrm{s}}\right)$ were determined between 10:00 and 12:00 h, at an irradiance of 400-600 $\mu \mathrm{mol}$ (photon) $\mathrm{m}^{-2} \mathrm{~s}^{-1}$, temperature of $30 \pm 0.5^{\circ} \mathrm{C}$, and $60-70 \%$ relative humidity, in three mature leaves per treatment, DAT interval and replicate, with a portable photosynthesis system ( $L C i, A D C$ BioScientific, UK). 
Photosynthetic pigments: Foliar discs with area of $1 \mathrm{~cm}^{2}$ were taken in triplicates from plants of each treatment and DAT interval, placed in assay tubes with $5 \mathrm{~mL}$ of $\mathrm{N}, \mathrm{N}$-dimethyl-formamide and kept in darkness for $24 \mathrm{~h}$, after which the absorbance values were read at 480, 647, and $664 \mathrm{~nm}$ using spectrophotometer (UV-Vis Multiscan Go, Thermo Scientific, Finland). The concentrations of chlorophyll (Chl) $a$ and $b$, total chlorophyll, and carotenoids were calculated according to Wellburn (1994).

Growth and foliar area: On completion of each treatment, the height $(\mathrm{cm})$ of each plant was measured and the samples were separated into leaves, stems, and roots. The total foliar area was determined per replicate, treatment, and DAT interval with a foliar area meter (LI-3100C, LI-COR BioSciences, Lincoln, NE, USA). The samples were dried at $60^{\circ} \mathrm{C}$ in a forced air oven (SHEL LAB, USA) to determine the dry mass of the foliar, stem, and root biomass.

Relative water content (RWC): This parameter was determined in the WD treatments using six foliar discs of $1 \mathrm{~cm}^{2}$ per replicate. The discs were weighed to obtain the fresh mass (FM) values, placed in $5 \mathrm{~mL}$ of distilled water at $5^{\circ} \mathrm{C}$ for $24 \mathrm{~h}$, dried with paper, and weighed to obtain the turgid mass (TM). They were then dried at $60^{\circ} \mathrm{C}$ in a $S H E L$ $L A B^{\circledR}$ forced air oven for $24 \mathrm{~h}$ to obtain the dry mass (DM). The RWC was then calculated according to Thameur et al. (2011):

$\mathrm{RWC}=100 \times(\mathrm{FM}-\mathrm{DM}) /(\mathrm{TM}-\mathrm{DM})$.

Abscisic acid (ABA): The concentration of ABA was determined after application of the flooding treatment, according to Khadri et al. (2006) and Kishwar et al. (2011). The fresh foliar material $(0.5 \mathrm{~g})$ was macerated with $5 \mathrm{~mL}$ of extraction solvent $\left(80 \%\right.$ methanol $+10 \mathrm{mg} \mathrm{L}^{-1}$ of butylated hydroxytoluene) and incubated at $4^{\circ} \mathrm{C}$ for $1 \mathrm{~h}$. It was then centrifuged $(6,800 \times g$ for $15 \mathrm{~min})$, and the supernatant collected. Two more successive extractions of the precipitate were conducted with $1 \mathrm{~mL}$ of extraction solvent. The resulting three supernatants were then combined and $30 \mathrm{mg}$ of polyvinylpolypyrrolidone (PVPP) added to eliminate plant pigments and other nonpolar compounds that could interfere with the immunoassay. The obtained solid was resuspended in $0.5 \mathrm{~mL}$ of Tris$\mathrm{HCl} 25 \mathrm{mM}$ buffer $\mathrm{pH} 7.5$, based on $100 \mathrm{mM} \mathrm{NaCl}$ and $1 \mathrm{mM} \mathrm{MgCl} 2$. Quantification of the ABA was conducted through an immunoassay (ELISA), using the specific $P G R-1$ detection kit for this hormone (PGR1-1KT, Sigma). Aliquots of $0.1 \mathrm{~mL}$ of sample and $0.1 \mathrm{~mL}$ of tracer solution were added to each well and incubated at $4^{\circ} \mathrm{C}$ for $3 \mathrm{~h}$. During this incubation, the ABA of the sample competes with the tracer molecule, which is linked to the enzyme alkaline phosphatase, to join with the monoclonal antibodies specific to ABA fixed to the ELISA plate. At the end of the incubation, two washes were performed with $0.1 \mathrm{~mL}$ of PBS Tween ${ }^{\circledR}$ solution, $0.2 \mathrm{ml}$ of substrate solution (paranitrophenyl phosphate) were added and the plates were incubated at $37^{\circ} \mathrm{C}$ for $60 \mathrm{~min}$ to produce the enzymatic reaction. The absorbance reading was conducted at $405 \mathrm{~nm}$ with a plate reader (UV-Vis Multiscan Go, Thermo Scientific, Finland). Quantification was conducted based on an ABA curve pattern $\left(0-1,000 \mathrm{pmol} \mathrm{mL}^{-1}\right)$.

Statistical analysis: The obtained data from two independent experiments were subjected to analysis of variance (ANOVA) separately. Previously, the assumptions of normality and variance homogeneity using AndersonDarling's and Levene's tests were applied to the data; and when hyphothesis was rejected data were transformed by Johnson transformation (Chou et al. 1998). Factors for the flooding experiment were the duration of flooding $(0,5$, and $10 \mathrm{~d})$ and DAT interval $(20,40,80$, and 120$)$. For the effect of water deficit, the factors considered were stress treatments $(100,70,50$, and $25 \%$ of water applied to FC) and DAT interval (40, 80, and 120). Data Tukey's means tests were performed $(P<0.05)$ using the program $S A S$ (SAS Institute 2010).

\section{Results}

Effects of flooding: Growth attributes and the concentration of photosynthetic pigments were significantly affected only by the flooding treatment of 10-d duration (Table 1, Fig. 1). The height of the chili plants was significantly reduced $(27.2 \%)$ when they were flooded for 10 consecutive days at the beginning of fructification (120 DAT). Similarly, a negative effect was observed for the total aerial biomass, leaf and root biomass at 120 DAT in plants flooded for $10 \mathrm{~d}$ (Fig. 1), while stem biomass was unaffected by the periods of flooding (Fig. 1).

Foliar area showed significant differences from 80 DAT with $10 \mathrm{~d}$ of flooding (Table 1), with yellowing and abscission of the lower leaves observed. At 120 DAT, rolling and senescence of the leaves was also observed, concurring with a reduction of $45.1 \%$ in leaf biomass found at $120 \mathrm{DAT}$ during this period. Likewise, the concentration of photosynthetic pigments was only affected by the stress through flooding for $10 \mathrm{~d}$ at 120 DAT (Table 1). The treatment of flooding for five consecutive days at all DAT intervals did not significantly affect the attributes of growth or the concentration of photosynthetic pigments (Table 1).

The photosynthetic characteristics of amashito chili were significantly affected from 20 DAT by both the duration of flooding and the DAT interval (Fig. 2). The rate of photosynthesis, rate of transpiration, and stomatal conductance showed reductions $(62.1-87.1 \%, 6.0-77.7 \%$, and $83.3-91.6 \%$, respectively) with the treatment of $5 \mathrm{~d}$ of flooding and, at 120 DAT, were close to zero. At 120 DAT and $10 \mathrm{~d}$ of flooding, the photosynthetic characteristics were completely inhibited. The significant reduction observed in stomatal conductance affected the entry of $\mathrm{CO}_{2}$ via the stomata and thus also affected the rate of photosynthesis.

In accordance with the reduction in $g_{\mathrm{s}}$, the ABA concentration exhibited an increase $(>100 \%)$ at 40 and 80 DAT with the flooding treatments, compared to the treatment with no flooding (Fig. 3). 
Table 1. Plant height, foliar area, and concentration of photosynthetic pigments in Capsicum annuum var. glabriusculum under flooding at different days after transplanting (DAT). Different letters within a column denote significant differences between treatment at $P<0.05$, according to the Tukey's test.

\begin{tabular}{lcccllll}
\hline $\begin{array}{l}\text { Flooding } \\
\text { period [d] }\end{array}$ & DAT & $\begin{array}{l}\text { Plant height } \\
{[\mathrm{cm}]}\end{array}$ & $\begin{array}{l}\text { Foliar area } \\
{\left[\mathrm{cm}^{2}\right]}\end{array}$ & $\begin{array}{l}\text { Chl } a \\
{\left[\mathrm{mg} \mathrm{g}^{-1}(\mathrm{FM})\right]}\end{array}$ & $\begin{array}{l}\text { Chl } b \\
{\left[\mathrm{mg} \mathrm{g}^{-1}(\mathrm{FM})\right]}\end{array}$ & $\begin{array}{l}\text { Total Chl } \\
{\left[\mathrm{mg} \mathrm{g}^{-1}(\mathrm{FM})\right]}\end{array}$ & $\begin{array}{l}\text { Carotenoids } \\
{\left[\mathrm{mg} \mathrm{g}^{-1}(\mathrm{FM})\right]}\end{array}$ \\
\hline 0 & 20 & $19.7^{\mathrm{e}}$ & $559^{\mathrm{c}}$ & $1.98^{\mathrm{de}}$ & $0.57^{\mathrm{d}}$ & $2.54^{\mathrm{d}}$ & $0.35^{\mathrm{ef}}$ \\
& 40 & $56.3^{\mathrm{c}}$ & $1,506^{\mathrm{c}}$ & $4.59^{\mathrm{b}}$ & $1.22^{\mathrm{bc}}$ & $5.81^{\mathrm{b}}$ & $0.87^{\mathrm{bc}}$ \\
& 80 & $114.5^{\mathrm{b}}$ & $6,464^{\mathrm{a}}$ & $4.78^{\mathrm{b}}$ & $1.44^{\mathrm{ab}}$ & $6.22^{\mathrm{b}}$ & $0.91^{\mathrm{bc}}$ \\
& 120 & $140.6^{\mathrm{a}}$ & $7,471^{\mathrm{a}}$ & $3.39^{\mathrm{bcd}}$ & $1.11^{\mathrm{bc}}$ & $4.50^{\mathrm{bc}}$ & $0.67^{\mathrm{cd}}$ \\
& 20 & $19.4^{\mathrm{e}}$ & $352^{\mathrm{c}}$ & $1.65^{\mathrm{e}}$ & $0.55^{\mathrm{d}}$ & $2.20^{\mathrm{b}}$ & $0.31^{\mathrm{f}}$ \\
& 40 & $46.7^{\mathrm{cd}}$ & $879^{\mathrm{c}}$ & $4.94^{\mathrm{b}}$ & $1.17^{\mathrm{bc}}$ & $6.11^{\mathrm{b}}$ & $0.87^{\mathrm{bc}}$ \\
& 80 & $111.5^{\mathrm{b}}$ & $6,504^{\mathrm{a}}$ & $4.82^{\mathrm{b}}$ & $1.32^{\mathrm{ab}}$ & $6.15^{\mathrm{b}}$ & $0.99^{\mathrm{b}}$ \\
& 120 & $141.7^{\mathrm{a}}$ & $6,556^{\mathrm{a}}$ & $2.44^{\mathrm{cde}}$ & $0.81^{\mathrm{cd}}$ & $3.25^{\mathrm{cd}}$ & $0.57^{\mathrm{de}}$ \\
& 20 & $32.9^{\mathrm{de}}$ & $385^{\mathrm{c}}$ & $1.64^{\mathrm{e}}$ & $0.64^{\mathrm{d}}$ & $2.27^{\mathrm{d}}$ & $0.33^{\mathrm{ef}}$ \\
& 40 & $46.2^{\mathrm{cd}}$ & $624^{\mathrm{c}}$ & $6.89^{\mathrm{a}}$ & $1.75^{\mathrm{a}}$ & $8.65^{\mathrm{a}}$ & $1.30^{\mathrm{a}}$ \\
& 80 & $110.2^{\mathrm{b}}$ & $4,084^{\mathrm{b}}$ & $3.55^{\mathrm{bc}}$ & $0.99^{\mathrm{bcd}}$ & $4.54^{\mathrm{bc}}$ & $0.80^{\mathrm{bcd}}$ \\
& 120 & $102.3^{\mathrm{b}}$ & $50^{\mathrm{c}}$ & $0.25^{\mathrm{f}}$ & $0.10^{\mathrm{e}}$ & $0.20^{\mathrm{e}}$ & $0.28^{\mathrm{f}}$ \\
\hline
\end{tabular}

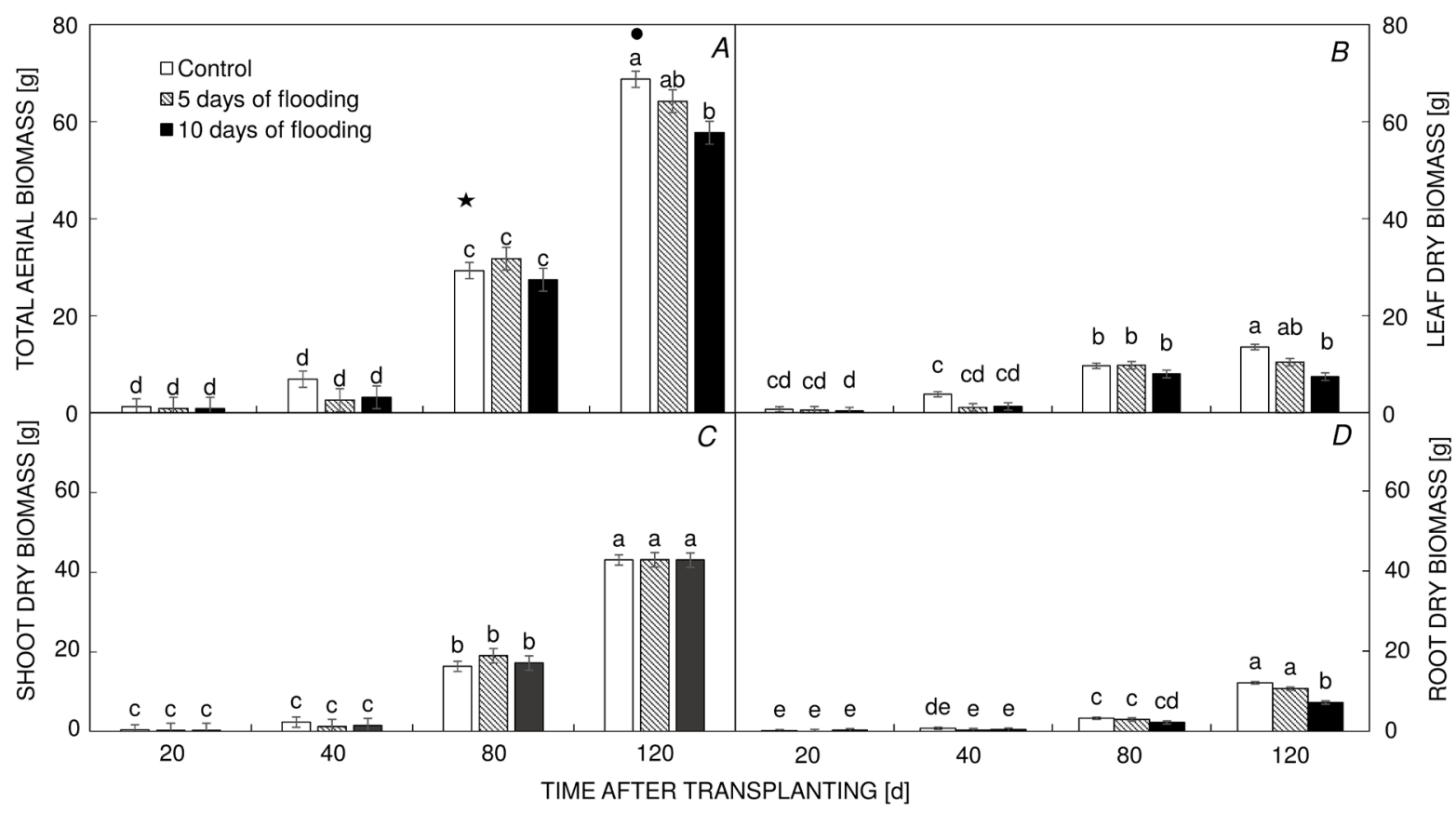

Fig. 1. Accumulation of total aerial biomass $(A)$, leaf biomass $(B)$, shoot biomass $(C)$, and root biomass $(D)$ in four stages of growth of Capsicum annuum var. glabriusculum under flooding. $\star$ Beginning of flowering. Beginning of fructification. Different letters within a column denote significant differences between treatments $(P<0.05)$, according to the Tukey's test $(P<0.05)$. Data represent means \pm standard error $(n=20)$.

Effects of water deficit: The water deficit treatments significantly reduced plant height at 80 (up to $36.5 \%$ ) and 120 DAT (up to $51.5 \%$ ). A similarly negative effect was observed on the total aerial biomass, shoot biomass, and root biomass at 80 and $120 \mathrm{DAT}$, at $70 \%$ water stress treatment. However, leaf biomass was reduced (up to 50\%) significantly from 40 DAT at all of the WD treatments evaluated (Fig. 4). Foliar area and specific foliar area both presented a significant reduction at all of the DAT intervals through the effect of water deficit (Table 2). The reduction in specific foliar area, especially at 120 DAT, indicates a thickening of the leaves due to the water deficit. In the leaves, significant differences in RWC were observed through the effect of the imposed water deficit from 80 DAT (Table 2).

The rates of $P_{\mathrm{N}}$ and $E$ diminished significantly with reduction in the levels of plant available water (Fig. 5) from 40 DAT. Plants at 40 DAT only exhibited lower $P_{\mathrm{N}}(25.5 \%)$ at $25 \%$ water stress treatment. Stomatal conductance diminished from 40 DAT at all of the levels of water stress 


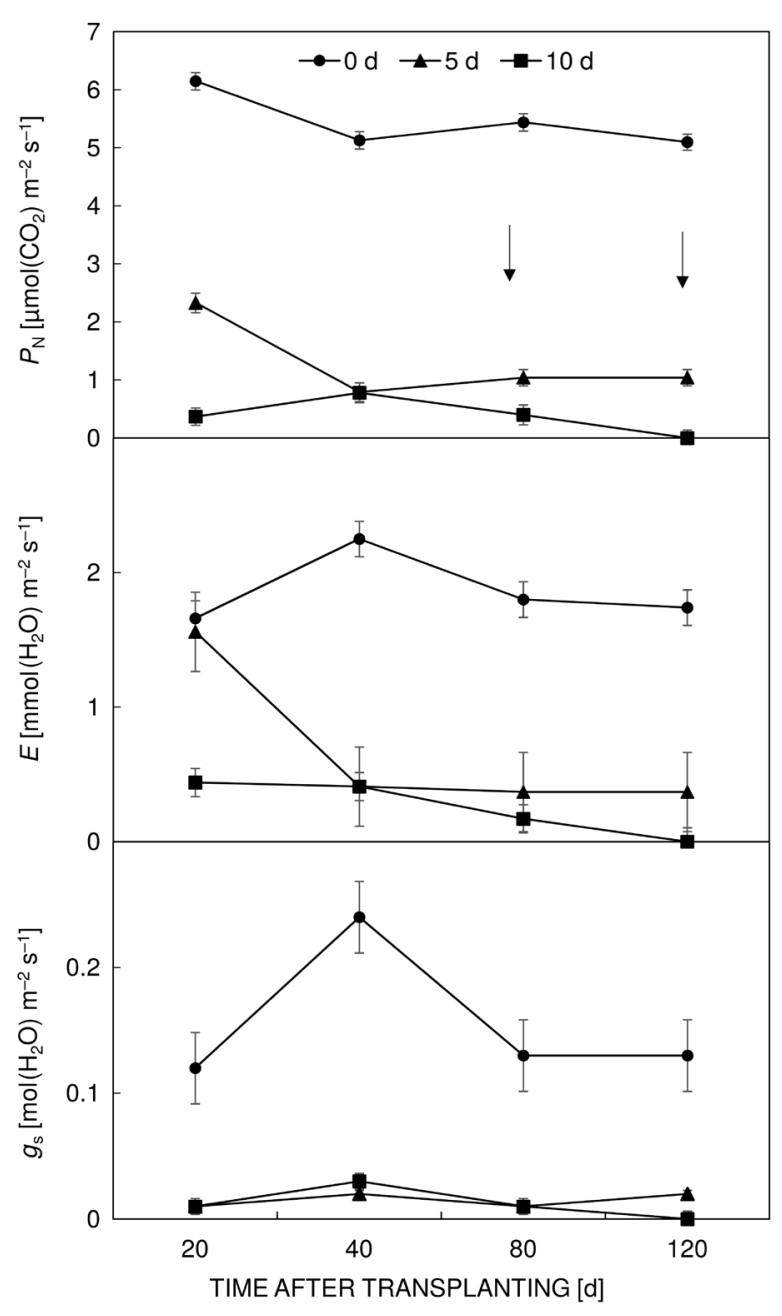

Fig. 2. Rate of photosynthesis $\left(P_{\mathrm{N}}\right)$, transpiration rate $(E)$, and stomatal conductance $\left(g_{\mathrm{s}}\right)$ at different times after transplanting (days) of Capsicum annuum var. glabriusculum under different periods of flooding. The arrows denote the flowering period. The data represent means \pm standard error $(n=20)$.

applied (Fig. 5). In plants at 80 and 120 DAT, $g_{\text {s }}$ was close to 0 at 70,50 , and $25 \%$ of plant available water indicating stomatal closure. Water-use efficiency (WUE) showed a significant increase with reduction in substrate moisture only in plants at 40 DAT (Fig. 5), possibly indicating a greater tolerance to stress at this age.

\section{Discussion}

The fact that the amashito chili develops in environmental conditions of the humid Mexican tropics, in which periods of high (up to $500 \mathrm{~mm}$ in a month during wet season) and low (up to $100 \mathrm{~mm}$ during dry season) precipitation alternate, appears not to cause a greater tolerance to water stress in this species. Both stresses (flooding and water deficit) affected the growth and photosynthetic parameters of the amashito chili plants, mainly during the phases of flowering and fructification. During these phases, the greater demand for assimilates by the forming fruits can

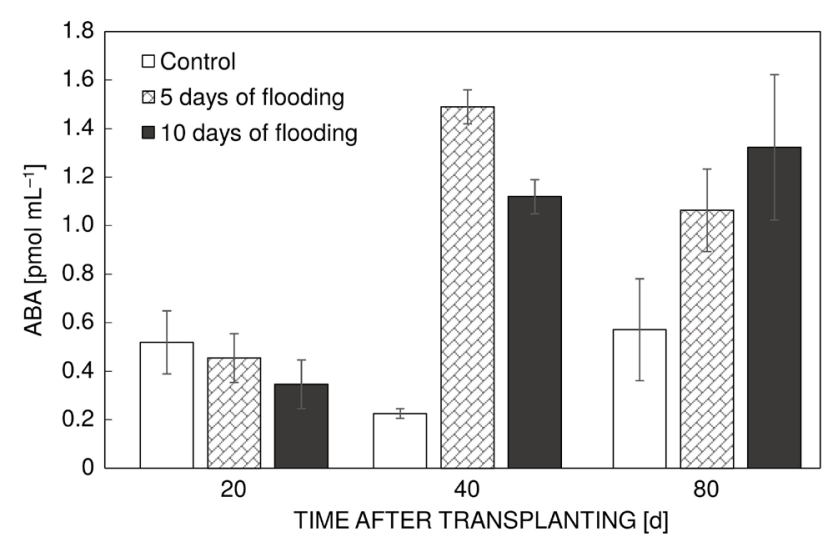

Fig. 3. Concentration of abscisic acid (ABA) in Capsicum annuum var. glabriusculum, at 20,40, and $80 \mathrm{~d}$ after transplanting and different periods of flooding. The data represent means \pm standard error $(n=15)$.

increase the effect of the stress, inducing the senescence and leaf fall with a prolonged duration of flooding, which affects the foliar area. In plants subjected to flooding, a generalized response, which has been documented, is a premature abscission and senescence of the leaves and suppression of the formation and expansion of new leaves (Kozlowski 1984). For the plant, this reduction in foliar area represents a strategy for saving energy during the effect of a stress, reducing respiration to maintain as low metabolism as possible (Jarma-Orozco et al. 2015). In Solanaceae, the negative effect of flooding on vegetative growth is also associated with low rates of photosynthesis (Ezin et al. 2010). However, the loss of roots and lack of oxygen in the rhizosphere of the plants has also been associated with yellowing, epinasty, necrosis, and leaf abscission (Aldana et al. 2014). In the chili plants flooded in this study, the reduction in the root biomass was observed at 120 DAT, probably caused by anoxia that induces the loss of activity and roots (Akhtar and Nazir 2013, Yang et al. 2016). During this period, the emission of adventitious roots was observed; these could reduce the stress caused by the deficiency of oxygen but do not compensate for the loss of roots.

The photosynthetic pigments diminished at 120 DAT (flowering) due to the leaf senescence promoted by flooding for $10 \mathrm{~d}$, indicating that this species does not tolerate flooding for periods greater than five days during this stage, although it does during the vegetative phase. Such a reduction in photosynthetic pigments through the effect of flooding has been observed in other species of Capsicum (Ou et al. 2011) and can reduce the functionality of the PSII (Campos et al. 2014), affecting rates of photosynthesis. This sensitivity to flooding in the amashito chili, mainly during the flowering stage and even when growing in humid tropical conditions, is reflected in the reduction of $P_{\mathrm{N}}, E$, and $g_{\mathrm{s}}$ values when subjected to periods of 5 and $10 \mathrm{~d}$ of flooding. In other Solanaceae, such as the tomato, a stomatal closure under conditions of flooding reduces the concentration of intracellular $\mathrm{CO}_{2}$ which explains the changes in $\mathrm{Chl}$ fluorescence parameters (Else et al. 2009). In commercial cultivars of Capsicum, 


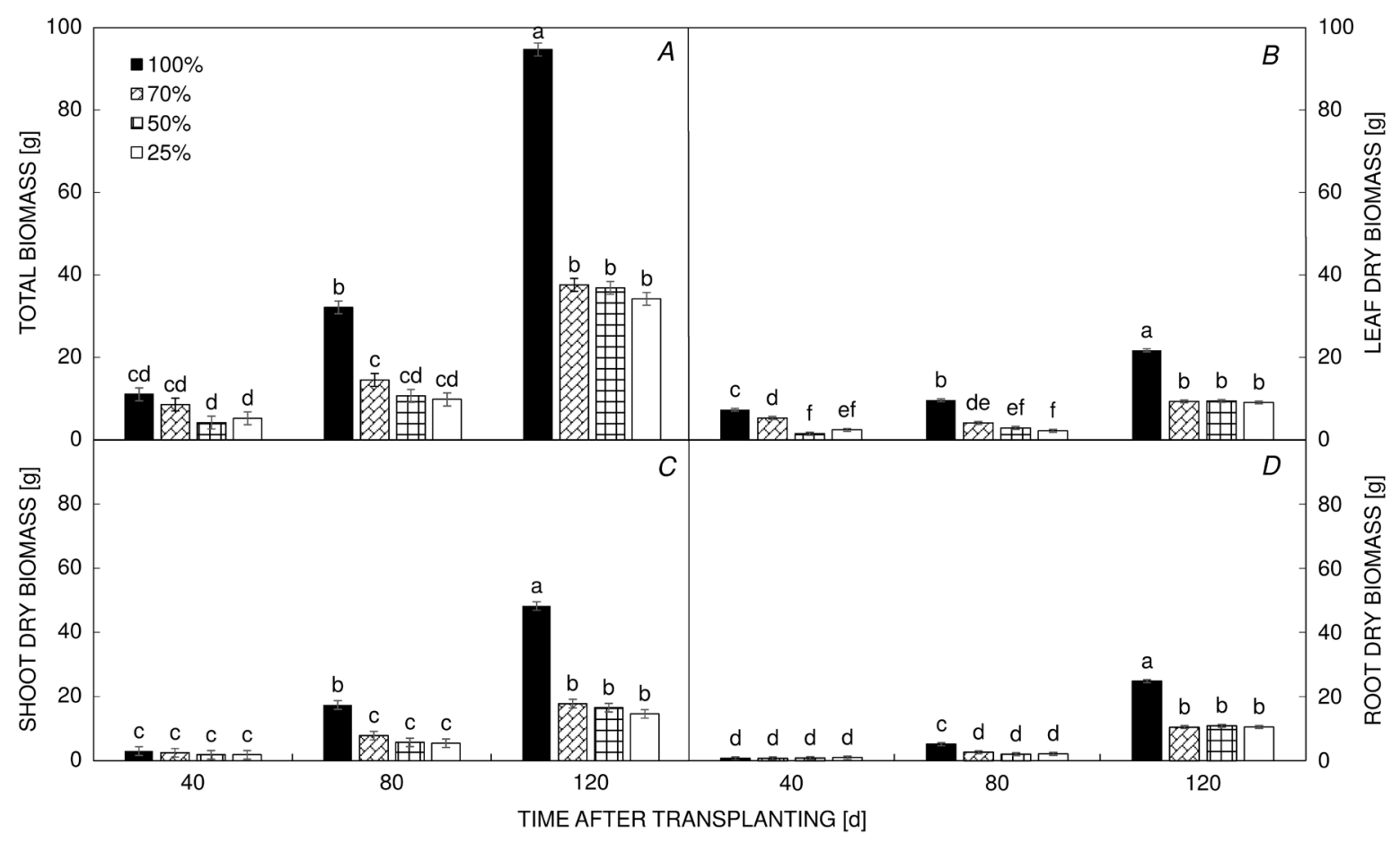

Fig. 4. Total aerial biomass $(A)$, leaf biomass $(B)$, shoot biomass $(C)$, and root biomass $(D)$ at different times after transplanting (days) in Capsicum annuum var. glabriusculum and levels of plant available water in the substrate $(100,70,50$, and $25 \%$ ). The same letters indicate no significant difference at $P<0.05$. The data represent means \pm standard error $(n=20)$.

Table 2. Plant height, foliar area, specific foliar area, and relative water content in Capsicum annuum var. glabriusculum under water deficit at 40,80, and $120 \mathrm{~d}$ after transplanting. Different letters within a column denote significant differences between treatments $(P<0.05)$.

\begin{tabular}{|c|c|c|c|c|c|}
\hline $\begin{array}{l}\text { Plant available } \\
\text { water [\%] }\end{array}$ & $\begin{array}{l}\text { Plant age } \\
{[\mathrm{DAT}]}\end{array}$ & $\begin{array}{l}\text { Plant height } \\
{[\mathrm{cm}]}\end{array}$ & $\begin{array}{l}\text { Foliar area } \\
{\left[\mathrm{cm}^{2}\right]}\end{array}$ & $\begin{array}{l}\text { Specific foliar area } \\
{\left[\mathrm{cm}^{2} \mathrm{~g}^{-1}\right]}\end{array}$ & $\begin{array}{l}\text { Relative water } \\
\text { content }[\%]\end{array}$ \\
\hline \multirow[t]{3}{*}{100} & 40 & $56.00^{\mathrm{ghi}}$ & $1,617.53^{d}$ & $223.40^{\mathrm{de}}$ & $51.06^{\mathrm{abc}}$ \\
\hline & 80 & $105.25^{\mathrm{b}}$ & $6,191.80^{b}$ & $646.80^{\mathrm{ab}}$ & $54.96^{\mathrm{ab}}$ \\
\hline & 120 & $127.50^{\mathrm{a}}$ & $7,568.48^{\mathrm{a}}$ & $348.61^{\mathrm{cd}}$ & $56.62^{\mathrm{a}}$ \\
\hline \multirow[t]{3}{*}{70} & 40 & $51.00^{\mathrm{hi}}$ & $1,319.60^{\text {def }}$ & $249.46^{\mathrm{d}}$ & $49.28^{\mathrm{abc}}$ \\
\hline & 80 & $85.00^{\mathrm{cd}}$ & $2,981.73^{\mathrm{c}}$ & $710.83^{a}$ & $34.71^{\mathrm{bcd}}$ \\
\hline & 120 & $91.25^{\mathrm{c}}$ & $439.90^{\text {efg }}$ & $46.95^{\mathrm{e}}$ & $38.11^{\mathrm{cd}}$ \\
\hline \multirow[t]{3}{*}{50} & 40 & $45.50^{\mathrm{i}}$ & $1,115.70^{\text {defg }}$ & $740.15^{\mathrm{a}}$ & $50.46^{\mathrm{abc}}$ \\
\hline & 80 & $74.25^{\mathrm{def}}$ & $1,394.20^{\mathrm{de}}$ & $485.38^{\mathrm{bc}}$ & $23.16^{\mathrm{d}}$ \\
\hline & 120 & $77.25^{\text {de }}$ & $405.60^{\mathrm{fg}}$ & $42.69^{\mathrm{e}}$ & $31.56^{\mathrm{cd}}$ \\
\hline \multirow[t]{3}{*}{25} & 40 & $46.00^{\mathrm{i}}$ & $1,106.25^{\text {defg }}$ & $503.20^{\mathrm{bc}}$ & $55.14^{\mathrm{ab}}$ \\
\hline & 80 & $66.75^{\mathrm{efg}}$ & $1,136.18^{\operatorname{defg}}$ & $517.33^{\mathrm{bc}}$ & $25.79^{d}$ \\
\hline & 120 & $61.75^{\mathrm{fgh}}$ & $339.78^{g}$ & $37.08^{\mathrm{e}}$ & $34.74^{\mathrm{bcd}}$ \\
\hline
\end{tabular}

Ismail and Davies (1997) showed reductions in $g_{\mathrm{s}}$ and $P_{\mathrm{N}}$ from just $24 \mathrm{~h}$ of flooding, arguing that the loss of root signaling, which occurs under these conditions, could be the cause of the stomatal closure. As shown by this study, previous studies of $C$. annuum indicate that stress by flooding produces increased ABA in the leaves, which seems to be implied in the reduced stomatal conductance and leaf growth (Ismail and Davies 1997).

The response of the amashito chili to water deficit was a reduction in growth and gas exchange at all stages of growth. A negative effect on the biomass has been observed in various species of Capsicum subjected to mild, moderate, and severe water deficits (Quintal et al. 2012). These reductions in biomass could be the result of reductions in the relative growth rate (RGR) as observed in C. annuum, C. chinense, and C. frutescens (Okunlola et al. 2017), in the foliar expansion and modification of the root growth (Kulkarni and Phalke 2009). The 


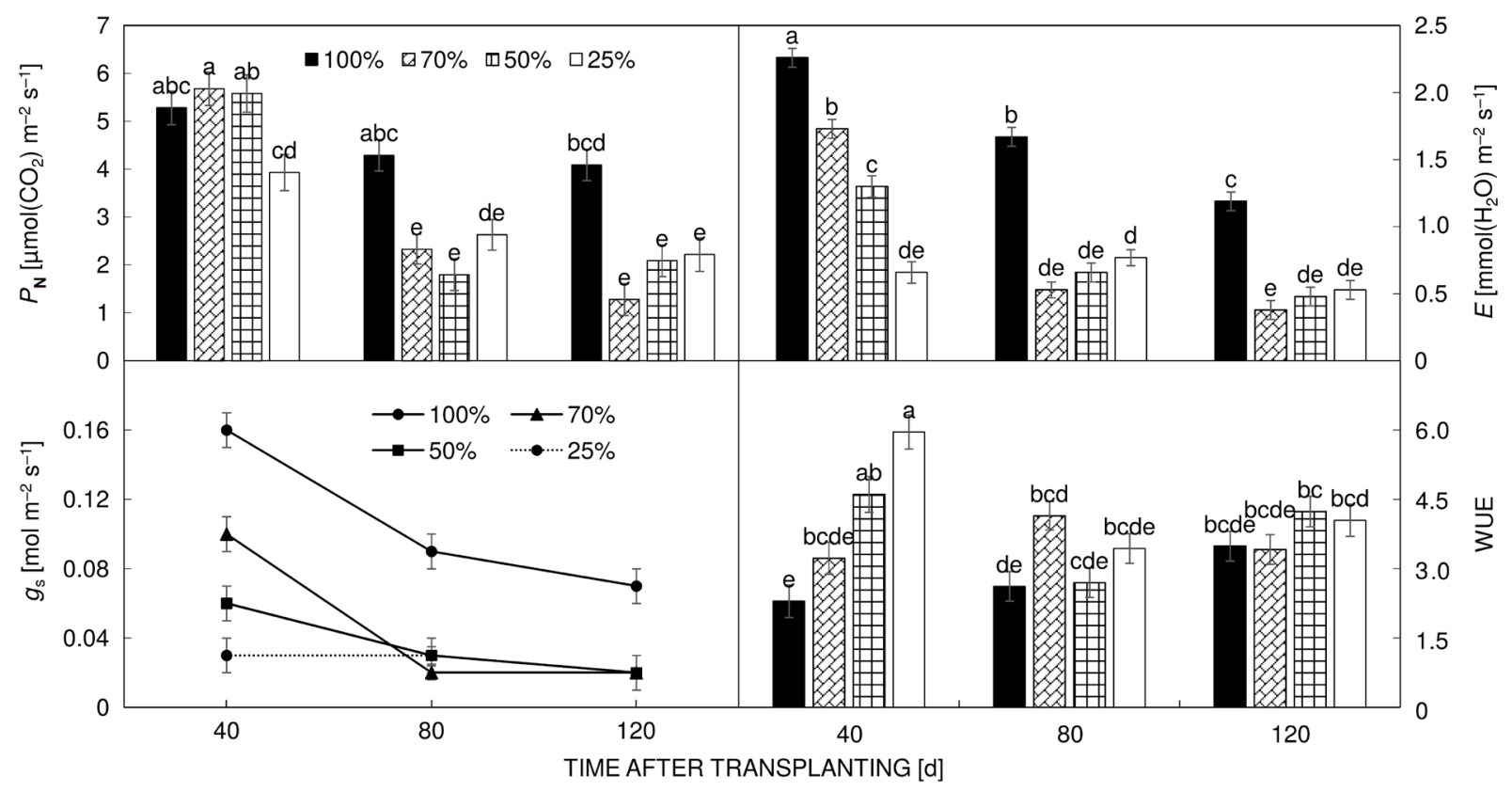

Fig. 5. Rate of photosynthesis $\left(P_{\mathrm{N}}\right)$, transpiration rate $(E)$, stomatal conductance $\left(g_{\mathrm{s}}\right)$, and water-use efficiency (WUE) of Capsicum annuum var. glabriusculum at different times after transplanting at $100,70,50$, and $25 \%$ of plant available water in the substrate. The same letters indicate no significant difference at $P<0.05$. The data represent means \pm standard error $(n=20)$.

diminished total foliar area reflects a reduced RGR and the senescence of mature leaves, given that it has been shown that both of these processes are accentuated under stress through water deficit (Nilsen and Orcutt 1996, Okunlola et al. 2017). The effect of the water deficit is also reflected in the RWC of the leaf, which was reduced from the treatment of $70 \%$ of plant available water at 80 DAT (beginning of flowering). In other species of Capsicum, this effect of the water deficit on the RWC can be presented in the vegetative stage as well as in flowering and fructification (Okunlola et al. 2017). The rates of photosynthesis and transpiration decreased due to the effect of the water deficit with $25 \%$ of plant available water at 40 DAT and with all of the levels of reduction of plant available water from 80 DAT. As with the flooding, it can be seen that the amashito chili is mainly sensitive to stress through water deficit during the stages of flowering and fructification. It has been indicated that this negative effect of the water deficit on the gas exchange is in response to the reduced stomatal conductance because of stomatal closure, and/or to changes in the photosynthetic metabolism (Osakabe et al. 2014), which translates into lower vegetative growth and yield. Okunlola et al. (2017) indicate that soil water contents of between $40-45 \%$ and $30-35 \%$ can significantly affect the functioning of plants of Capsicum and reduce their yield.

Conclusion: In this study, stress by flooding presented a negative effect on the vegetative development of the amashito chili at 120 DAT, affecting the production of leaf and root biomass, as well as the concentration of photosynthetic pigments. In contrast, $P_{\mathrm{N}}, E$, and stomatal conductance were affected by the flooding from 20 DAT, with effects on the accumulation of aerial biomass only observed at 120 DAT. Similarly, the stress caused by water deficit showed negative effects on the vegetative development, affecting leaf, stem, and root biomass. The $P_{\mathrm{N}}, E$, and stomatal conductance also decreased as a function of the levels of plant available water in the substrate.

According to these results, the excess or deficiency of water produces alterations in the physiology of the amashito chili plants that affect the production of biomass during both the vegetative and reproductive stages. On the one hand, the permanence of local populations can be affected, particularly if variations in rainfall intensify due to climate changes. On the other hand, these data should be taken into account when establishing strategies of cultivation and management of this species under the environmental conditions of the humid tropics.

\section{References}

Aguilar-Meléndez A., Morrel P.L., Roose M., Kim S.C.: Genetic diversity and structure in semiwild and domesticated chiles (Capsicum annuum; Solanaceae) from Mexico. - Am. J. Bot. 96: 1190-1202, 2009.

Akhtar I., Nazir N.: Effect of waterlogging and drought stress in plants. - Int. J. Water Res. Environ. Sci. 2: 34-40, 2013.

Alcalá-Rico J.S.G.J., López-Benítez A., Vázquez-Badillo M.E. et al.: Seed physiological potential of Capsicum annuum var. glabriusculum genotypes and their answers to pre-germination treatments. - Agronomy 9: 325, 2019.

Aldana F., García P.N., Fischer G.: Effect of waterlogging stress on the growth, development and symptomatology of cape gooseberry (Physalis peruviana L.) plants. - Rev. Acad. Colomb. Cienc. 38: 393-400, 2014.

Alonso B.R.A., Zambrano C.B., Ponce D.P. et al.: [Analysis of the morphometric characteristics and the site in relation to the variability of the timpinchile (Capsicum annuum $\mathrm{L}$. var glabriusculum sin aviculare).] - Quehacer Científico en 
Chiapas 1: 37-50, 2010. [In Spanish]

Anjum S.A., Xie X.-Y., Wang L.-C. et al:: Morphological, physiological and biochemical responses of plants to drought stress. - Afr. J. Agr. Res. 6: 2026-2032, 2011.

Antonio A.S., Wiedemann L.S.M., Veiga Junior V.F.: The genus Capsicum: a phytochemical review of bioactive secondary metabolites. - RSC Adv. 8: 25767-25784, 2018.

Arreguín-Cortés F.I., Rubio-Gutiérrez H., Domínguez-Mora R. et al.: [Analysis of the floods in the Tabasco plain in the period 1995-2010.] - Tecnologías y Ciencias del Agua 5: 5-32, 2014. [In Spanish]

Blum A.: Plant Breeding for Water Limited Environments. Pp. 11-52. Springer, New York 2011.

Calanca P.P.: Effects of abiotic stress in crop production. - In: Ahmed M., Stockle C.O. (ed.): Quantification of Climate Variability, Adaptation and Mitigation for Agricultural Sustainability. Pp. 165-180. Springer, Cham 2017.

Campos H., Trejo C., Peña-Valdivia C.B. et al.: Stomatal and non-stomatal limitations of bell pepper (Capsicum annuиm L.) plants under water stress and re-watering: delayed restoration of photosynthesis during recovery. - Environ Exp. Bot. 98: 56-64, 2014.

Cano-Vázquez A., López-Peralta M.C., Zavaleta-Mancera H.A. et al.: [Variation in seed dormancy among accessions of chile piquin (Capsicum annuum var. glabriusculum).] - Bot. Sci. 93: 1-10, 2015. [In Spanish]

Castañón-Nájera G., Latournerie-Moreno L., Lesher-Gordillo J.M. et al.: [Identification of variables to morphologically characterize collections of pepper (Capsicum spp.) in Tabasco, Mexico.] - Universidad y Ciencia, Trópico Húmedo 26: 225-234, 2010. [In Spanish]

Chou Y-M., Polansky A.M., Mason R.L.: Transforming nonnormal data to normality in statistical process control. J. Qual. Technol. 30: 133-141, 1998.

Cramer G.R., Urano K., Delrot S. et al.: Effects of abiotic stress on plants: a systems biology perspective. - BMC Plant Biol. 11: 163, 2011.

Else M.A., Janowiak F., Atkinson C.J., Jackson M.B.: Root signals and stomatal closure in relation to photosynthesis, chlorophyll $a$ fluorescence and adventitious rooting of flooded tomato plants. - Ann. Bot.-London 103: 313-323, 2009.

Ezin V., De La Pena R., Ahanchede A.: Flooding tolerance of tomato genotypes during vegetative and reproductive stages. Braz. J. Plant Physiol. 22: 131-142, 2010.

Galle A., Florez-Sarassa I., Tomas M. et al.: The role of mesophyll conductance during water stress and recovery in tobacco (Nicotiana sylvestris): acclimation or limitation? J. Exp. Bot. 60: 2379-2390, 2009.

Gray S.B., Brady S.M.: Plant developmental responses to climate change. - Dev. Biol. 419: 64-77, 2016.

Gunawardena M.D.M., De Silva C.S.: Identifying the impact of temperature and water stress on growth and yield parameters of chilli (Capsicum annuum L.). - OUSL J. 17: 25-42, 2014.

Hayano-Kanashiro C., Gámez-Meza N., Medina-Juárez L.Á.: Wild pepper Capsicum annuum L. var. glabriusculum: taxonomy, plant morphology, distribution, genetic diversity, genome sequencing, and phytochemical compounds. - Crop Sci. 56: 1-11, 2016.

Ismail M.R., Davies W.J.: Water relations of Capsicum genotypes under water stress. - Biol. Plantarum 39: 293-297, 1997.

Jarma-Orozco A., Mercado-Fernández T., Cleves-Leguizamo J.A.: [Effect of flooding on stevia (Stevia rebaudiana Bertoni) growth parameters.] - Rev. U.D.C.A Actualidad \& Divulgación Científica 18: 393-399, 2015. [In Spanish]
Khadri M., Tejera N.A., Lluch C.: Alleviation of salt stress in common bean (Phaseolus vulgaris) by exogenous abscisic acid supply. - J. Plant Growth Regul. 25: 110-119, 2006.

Kishwar A., Singh G.R., Niwas R.: A rapid method for estimation of abscisic acid and characterization of ABA regulated gene in response to water deficit stress from rice. - Am. J. Plant Physiol. 6: 144-156, 2011.

Kozlowski T.T.: Plant responses to flooding of soil. - BioScience 34: 162-167, 1984.

Kulkarni M., Phalke S.: Evaluating variability of root size system in hot pepper Capsicum annum L. under water stress. - Sci. Hortic.-Amsterdam 120: 159-166, 2009.

Liang G., Liu J., Zhang J.: Effects of drought stress on photosynthetic and physiological parameters of tomato. J. Am. Soc. Hortic. Sci. 145: 12-17, 2020.

Nilsen E.T., Orcutt D.M.: Physiology of Plants under Stress: Abiotic Factors. Pp. 704. John Wiley and Sons, New York 1996.

Okunlola G.O., Olatunji O.A., Akinwale R.O. et al.: Physiological response of the three most cultivated pepper species (Capsicum spp.) in Africa to drought stress imposed at three stages of growth and development. - Sci. Hortic.-Amsterdam 224: 198-205, 2017.

Osakabe Y., Osakabe K., Shinozaki K., Tran L.-S.P.: Response of plants to water stress. - Front. Plant Sci. 5: 86, 2014.

Ou L.J., Dai X.Z., Zhang Z.Q., Zou X.X.: Responses of pepper to waterlogging stress. - Photosynthetica 49: 339-345, 2011.

Ou L.J., Liu Z.B., Zhang Y.P., Zou X.X.: Effects of exogenous $\mathrm{Ca}^{2+}$ on photosynthetic characteristics and fruit quality of pepper under waterlogging stress. - Chil. J. Agr. Res. 77: 126133, 2017.

Pickersgill B.: Relationships between weedy and cultivated forms in some species of peppers (genus Capsicum). - Evolution 25: 683-691, 1971.

Porter R.H., Durrell M., Romm H.: The use of 2,3,5-triphenyltetrazoliumchloride as a measure of seed germinability. Plant Physiol. 22: 149-159, 1947.

Prado-Urbina G., Lagunes-Espinoza L.C., García-López E. et al.: [Germination of wild chili seeds in response to pre-germination treatments.] - Ecosistemas y Recursos Agropecuarios 2: 139149, 2015. [In Spanish with English abstract]

Quintal O.W.C., Pérez-Gutiérrez A., Latournerie L. et al.: [Water use, water potential and yield of habanero pepper (Capsicum chinense Jacq.).] - Rev. Fitotec. Mex. 35: 155-160, 2012. [In Spanish with English abstract]

Salinas H.R.M., Liévano L.E.A., Ulín Montejo F. et al.: [Morphological characterization and changes during the postharvest life of four types of amashito chile (Capsicum annuиm L.) var. glabriusculum (Duna) Heiser \& Pickersgill.] Revista Iberoamericana de Tecnología de Postcosecha 11: 92-100, 2010. [In Spanish]

SAS Institute.: SAS System for Windows. Release 9.3. SAS Institute, Cary, North Carolina 2010.

Thameur A., Ferchichi A., López-Carbonell M.: Quantification of free and conjugated abscisic acid in five genotypes of barley (Hordeum vulgare L.) under water stress conditions. S. Afr. J. Bot. 77: 222-228, 2011.

Wellburn A.R.: The spectral determination of chlorophylls $a$ and $b$, as well as total carotenoids, using various solvents with spectrophotometers of different resolution. - J. Plant Physiol. 144: 307-313, 1994.

Yang B.Z., Liu Z.B., Zhou S.D. et al.: Exogenous $\mathrm{Ca}^{2+}$ alleviates waterlogging-caused damages to pepper. - Photosynthetica 54: 620-629, 2016.

(C) The authors. This is an open access article distributed under the terms of the Creative Commons BY-NC-ND Licence. 